\section{Carl Nielsen til sin samtid}

Af forfatter, konsulent John Fellow Larsen

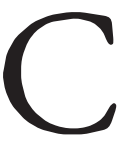

arl Nielsen skrev andet end erindringsbogen Min fynske Barndom og artikelsamlingen Levende

Musik. Igennem hele livet ytrede han sig om sine værker og om kunsten og livet $\mathrm{i}$ øvrigt i små og større artikler, i interviews, i foredrag og værknoter. Alt hvad han skrev og sagde, havde en anledning og tog udgangspunkt $i$ en konkret situation. På den måde fik han udtrykt adskilligt, som ofte peger ud over dagen og vejen, og som altid er en uvurderlig kilde til manden og hans værker, deres tilblivelse og deres møde med samtidens kunst og samfund.

Også de 9 artikler i Levende Musik blev til i konkrete situationer over en lang årrække, men har i kraft af udgivelsen i bogform i 1925 og de mange senere udgaver fået en problematisk status som Nielsen-æstetikken, skønt Carl Nielsen netop aldrig skrev en sådan - og altså også skrev og sagde så meget andet.

Nogle af Carl Nielsens artikler og interviews har været citeret rundt omkring i den eksisterende navnlig ældre litteratur om Carl Nielsen, ofte uden præcis kildeangivelse, undertiden forkert dateret og løsrevet fra deres sammenhæng. Andre blev i 1965 opregnet i Dan Fogs og Torben Schousboes værkforregnelse, der rummer 55 tekstnumre, og endelig har Torben Schousboe i noterne til sin dagbogsudgave fra 1983 yderligere nævnt et mindre antal.

Til disse i princippet i Carl Nielsen-litteraturen kendte, men ikke tidligere samlede artikler, interview og værknoter føjer sig et stort antal, som er nyfundet i udklipssamlinger på Det Kongelige Bibliotek, Carl Nielsen Museet i Odense og hos private. Arbejdet med at identificere og kommentere disse ofte anonyme udklip har derefter ført frem til flere artikler og interview, og ved at søge på centrale datoer $\mathrm{i}$ komponistens liv i de vigtigste blade og aviser er der dukket yderligere materiale op. Endelig kan disse artikler, interview og værknoter suppleres med et antal manuskripter til foredrag og taler, som Carl Nielsen har holdt, og med et antal skitser og notater, som ikke har været færdiggjort til offentliggørelse.

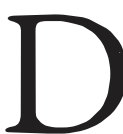

et siger sig selv, at de få søgemidler, som findes til tidsskrifter, blade og aviser i den periode fra ca. 1890 til 1931, hvori Carl Nielsen var skabende komponist og en offentlig person, har været konsulteret, men der er derved intet fundet, som ikke allerede var kendt. Der har ikke været nogen let vej til indsamlingen af Carl Nielsens ytringer, som optræder i så mange forskelligartede publikationer, at man må sige, at fuldstændighed forudsætter gennemsøgning af alt, hvad der er udgivet i den nævnte periode.

Den samling på 240 numre, som til efteråret udkommer i Carl Nielsen Udgavens regi på forlaget Gyldendal, prætenderer altså ikke at være komplet, men søgearbejdet, der har strukket sig 
over adskillige år, er ført så dybt, at arbejdsindsatsen ved fortsat søgning ikke længere står i et blot rimeligt forhold til udbyttet - og til behovet for en indsats over for udforskningen af andre sider af Carl Nielsen. Samlingen rummer alt, hvad udgiveren har haft kendskab til på udgivelsestidspunktet, og det meste vil være nyt for de fleste. Levende Musiks enkelte artikler er placeret i deres oprindelige sammenhæng og udgives her for første gang, som de øvrige 231 numre, i en tekstkritisk og kommenteret udgave, der både kaster nyt lys over dem og bevarer deres væsentlighed.

Som Carl Nielsens artikler, interview og værknoter fremlægges, for hovedpartens vedkommende ordnet kronologisk, rummer samlingen ikke blot, hvad han skrev og sagde med henblik på offentligheden om sin egen musik, om andres musik, om musikken $\mathrm{i}$ det hele tager og om en hel buket af andre emner, den tegner også et billede af Carl Nielsen set forfra, sådan som samtiden og dens medier oplevede ham og formede ham, og som han selv reagerede på samtidens udfordringer og formning. At se Carl Nielsen ud fra hans samtid er andet og mere end at reducere ham til den; det kan også være et værn imod at reducere ham til samtidens og til det billede af ham, vi har overtaget og bygget videre på i overensstemmelse med vor samtid.

Som smagsprøve følger her det sidste interview $i$ en hel række, som han gav i forbindelse med udgivelsen af $\mathrm{Min}$ fynske Barndom i efteråret 1927, offentliggjort i Hver 8 Dag, torsdag 15.12. 1927.

\section{Den fynske Tonemester.}

$\mathrm{E}$ t Besøg hos Komponisten Carl Nielsen, som fortæller om sine Barndomserindringer og sit Syn paa Kunst og Mennesker.

Carl Nielsen Musik kan være som Sværd, der krydses, og Blæst, der piber i Takkelage, og fjerne Lurer, - der er Slægtsfølelse i den, den har det dybe Perspektiv, som forbinder den levende Tid med alle de døde. Men midt i denne mandige, sunde Kraft kan en Tone af Blidhed og Ynde saa pludselig bryde sig Vej som en Solstraale gennem Drivskyer.

Og saadan er naturligvis ogsaa Carl Nielsen selv, som alle ægte Kunstnere ligner han sit Værk.

Mens man sidder overfor ham $i$ hans Hjem i den lave, gule Kaserne ved Frederiksholms Kanal, og han fortæller om sin Barndom i Nørre-Lyndelse og sit Syn paa Kunst og Mennesker, glider der hvert Øjeblik et Smil over hans myndige Ansigt under de stridige graa Haarbørster, et Solstrejf af fynsk Foraar.

- Hvorfor skriver De kun om

Deres Barndom?

- Jo, for den er et afsluttet

Hele, jeg kan se paa ham, som det slet ikke var mig selv, den lille Dreng derovre paa Fyn. Ja, Erindringerne gaar for Resten op til mit 18de Aar, da jeg kom til København og et nyt Afsnit begyndte; men er man andet end en stor Dreng endnu, naar man er sytten? Naa, det er i Grunden ikke mig selv, der har fundet paa at skrive mine Memoirer, det er min ældste Datter, som saa ofte, naar jeg fortalte mine Børn om min Barndom, sagde: Skriv det ned engang. $\mathrm{Og}$ nu har jeg altsaa gjort det. 
- Var Deres Forældre fattige?

- Ja, de sad i alt Fald i meget

smaa Kaar og med en stor Børneflok; men hvor vi havde det dejligt, der var Lykke og Harmoni i mit Barndomshjem, vi elskede hinanden, vi Sødskende, og vi legede og tumlede og var fuldkommen Naturbørn. Og de tusinde smaa Ting i Hverdagslivet blev store og betydningsfulde for os.

I det hele taget: Jeg tror ikke, Penge gør Mennesker lykkelige. De gør dem snarere lidt afstumpede og snævre, og de hindrer dem $i$ at udfolde deres Evner fuldtud. De behøver det jo ikke, og man skal være nødt til at arbejde og kæmpe med Stoffet, med Omgivelserne og med sig selv. Ellers bliver man ikke en Personlighed, og man føler heller ikke den usigelige Lykke, som det er at sidde alene med sit Arbejde og pludselig mærke, at nu lykkes det, nu er Kvaler og Kampe med Stoffet forbi, nu strommer det.

Kunst bevidst?

- En Kunstner maa være sig sin

- Ja, Hjerne maa der til, og jeg for mit Vedkommende kan ikke gribes af et Kunstværk, som ikke vidner om en høj Intelligens, en klar, skarp Logik, først naar alt dette er der, interesserer jeg mig for Følelsen bag Formen.

\section{Carl Nielsen og Sokrates}

S aadan husker jeg, med hvilken Bevægelse jeg i sin Tid læste Sokrates' Forsvarstale: Roligt, klart, med ubønhørlig Logik paaviste han sin Uskyldighed og fastslog, at man hellere burde have bespist ham paa Prytanneion' end dømme ham til Døden, og

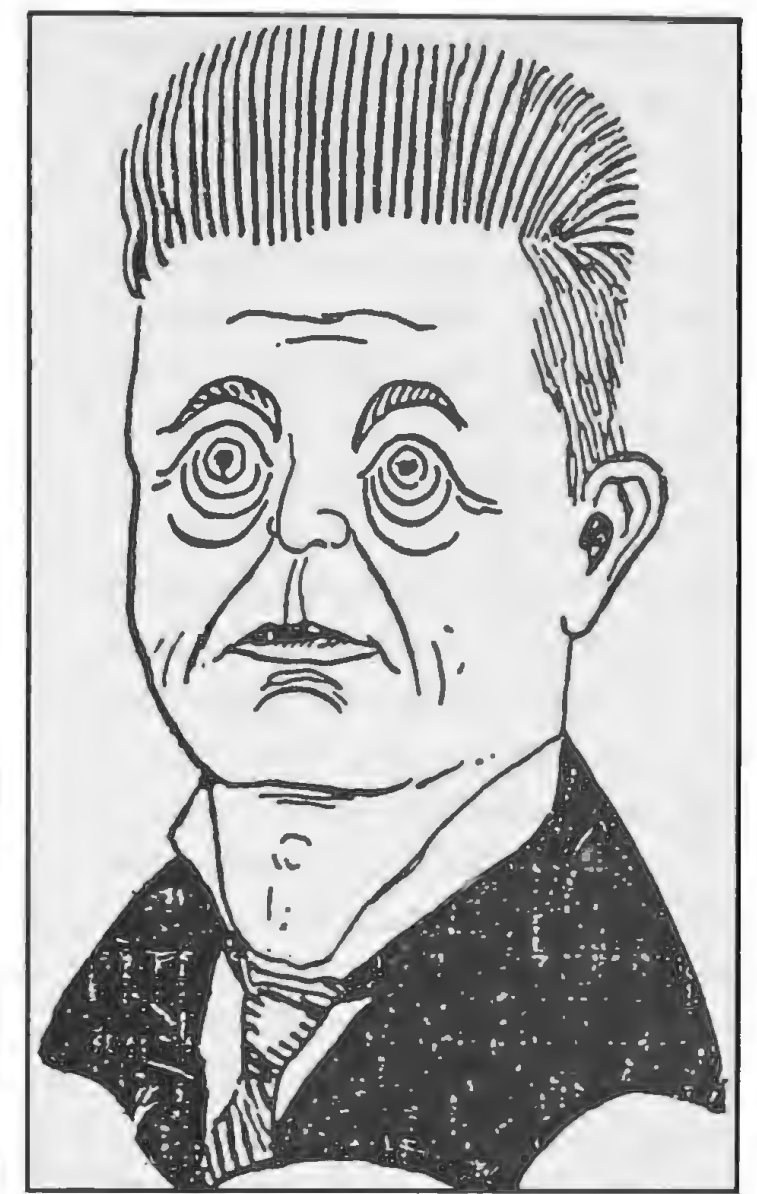

Carl Nielsen, tegnet af P.E. Johannessen, $i$ Musik, 2. årg. no. 3, 1. marts 1918.

med hele Visdommens Vægt sagde han til sine Dommere: Tænk vel paa, hvad I gør, at I ikke siden skal angre det!

Denne klare, mandige Logik, denne roligt, beherskede Aandsstyrke bragte mig ved Læsningen i den heftigste Bevægelse, mere end alle hjerteskærende Klager vilde have kunnet gøre det, - i det Plan har jeg mit Følelsesleje. Jeg hader tomme Ord og tomme Toner, der maa være en indre Værdi i hvert Ord og hver Tone, alt maa have kostet sin Pris. Derfor er der saa meget baade i moderne Digtning og i moderne Musik, jeg ikke kan goutere, fordi det ikke virker ægte 
paa mig, men som Industri eller gold Eksperimenteren. Jeg bryder mig kun om et Menneskes ægte Tale i Ord og Toner. Saa snart vi kommer bort fra vor Natur, bliver vi krampagtige. Og al denne Snak om Hjerte paa Bekostning af Hjerne, tror jeg ikke paa. Hvad er Følelse og hvad er Tanke? Som siamesiske Tvillinger er de uadskillelige fra hinanden, det er det Poul Martin Moller saa udmærket har udtrykt saaledes:

Naar uden Rod Violen gror i

Vang,

Tanker! ${ }^{2}$

Mads digter skønt foruden

Lad Tankerne blomstre i din Hjerne, lad Arbejdet anspænde alle dine Kræfter, og Følelsen vil komme af sig selv og bygge med paa Værket.

- Egentlig føler De Dem vel ikke videre i Harmoni med Tiden, De lever i?

\section{Musikalsk Cocktail}

$-A$ anej, jeg synes, det er ubehageligt at se, hvor Sansen for Stil udslettes, alt rystes sammen til en musikalsk Cocktail, Stort og Smaat er ikke til at skelne fra hinanden og Kontrastvirkningen, der skaber de aandelige Vitaminer, forsvinder.

- Tror De, det er en Overgangs- eller en Nedgangsperiode, vi lever i?

- Jeg haaber, at det er en Overgangstid, det byder min sunde Optimisme mig at tro, og for Resten viser Historiens Gang os jo, at alt gaar $\mathrm{i}$ Bølgedal. Men for Tiden er Sansen for dé egentlige $V æ r d i e r$ ringe, man nøjes med en Narresut, baade kunstnerisk og politisk. Man siger f. Eks. Konservatisme eller Radikalisme eller Socialisme uden at gøre sig klart, hvad det er. Det er tomme Slagord, bag hvilke de levende Mennesker gemmer sig. Grænserne mellem os er ikke saa skarpe, som man tror.

\section{Politik og Menneskelighed}

T eg har selv en Broder, som var radikal Folketingsmand ${ }^{3}$, og naar jeg sommetider har siddet sammen med ham oppe i "Snapstinget" og hørt Politikerne tale om hinanden, saa mærkes det jo, hvordan det menneskelige bryder Partidisciplinen, og den Anerkendelse og Sympati, som er bandlyst i Folketingssalen, kommer frit til Orde. Saadan flytter Nissen med overalt, og saadan tror jeg ogsaa, vi en Dag vil opleve, at vor Tids overdrevne Nøgternhed og Materialisme vil give Bagslag, en Dag vil Stemningslivet, Digtningen i os, Drømmen, kræve sin Ret, for vi digter jo allesammen, hvert Indtryk, vi modtager, er et Digt vi gemmer $\mathrm{i}$ os, om det nogensinde faar Form, er et Spørgsmaal om Tid og Kraft og Taalmodighed og Kultur, men det er der indeni os alle.

\section{De store Portaler}

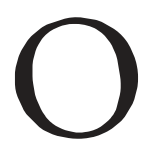
g det er jo de samme store Problemer, vi alle maa tumle med: Fødsel, Liv og Død, ingen kommer udenom de tre store Portaler, og selve Kampen for at bevare os selv materielt, uden at gaa tilgrunde aandeligt, hvad er det andet end den ældgamle og evigunge Kamp mellem Plebejere og Patriciere? Vel at mærke: Plebejere saavel 
som Patriciere kan man møde i alle Lag og Lejre. Jeg kender højtstaaende Folk, som er Plebejere, og jeg mødte forleden herude ved Frederiksholms Kanal en Brolægger, som talte saa henrivende smukt og mandigt om sit Hjem og sin Slægt, sine Børn, sine Sorger og Glæder, sin Stump Have, at jeg fik den største Sympati for ham og tænkte: Det er jo en Patriciersjæl, trods det beskedne Ydre. - Men for den lille Landsbydreng i Nørre-Lyndelse eksisterede alle den Slags Problemer vel ikke?

$\mathrm{Nej}$, da var man endnu ubevidst, anede ikke selv, hvad der gærede i En, og Tilværelsen var en daglig Opdagelsesrejse. Det er forunderligt at tænke tilbage paa for ethvert Menneske,
Noter

1 Prytaneion, rådhuset i det gamle Athen, hvor borgere, der havde udmærket sig til gavn for staten som en hædersbevisning blev indbudt til at spise med rådets medlemmer.

2 Poul Martin Møller, 1794 - 1838, digter og filosof, hvis 7. epigram (Efterladte Skrifter,

3. udgave, Kbh. 1855, I s. 41) lyder: "Hvis uden Rod Violen groer i Vang, hvis uden Krop en Skygge vanker, hvis uden Klokke Klokkeklang: Mads skriver skjønt foruden Tanker." først nu forstaar man jo sin Barndom og sin Slægt og sine Venner. Derfor har det været mig en Glæde at vende tilbage til "det tabte Land"4, som Johs. V. Jensen siger, Barndommens foraarsgrønne Egne, og i Tankerne være sammen med alle de kære Mennesker igen, og Dyrene, ja for Mennesker og Dyr staar mit Hjerte nærmere end selve Naturen. Først gennem det Liv, der knytter sig til Naturen, bliver den levende og dyrebar for mig. Derfor forstaar jeg heller ikke den Lyrik, som er ren Natur-Lyrik, det er som afskaarne Blomster eller som Amatørfotografier. Et Digt maa ville noget, pretendere noget, samle i en Perle en Sum af Viden og Tanker og Følelser, ellers er det en flov og ofte vammel aandelig Føde ....

3 Valdemar Emil Nielsen, 3.2.1871 - 1965, førstelærer ved Bryndum Skole 1898 1949, valgt til folketinget for Det radikale Venstre 1918 - 1926, jvf. interview med Valdemar Nielsen, Politiken 3.2.1956.

4 Titlen på første del - men ikke den først skrevne og udgivne del - af Johannes V. Jensens romanrække Den lange Rejse, der udkom fra 1908 - 1922, Det tabte Land udkom 1919. 